\title{
Techno-economic and environmental analysis of an Aquifer Thermal Energy Storage (ATES) in Germany
}

\author{
Simon Schüppler ${ }^{\text {*}^{*}}$, Paul Fleuchaus ${ }^{2}$ and Philipp Blum²
}

\author{
*Correspondence: \\ Simon.Schueppler@eifer.org \\ ${ }^{1}$ European Institute \\ for Energy Research (EIFER), \\ Emmy-Noether-Straße 11, \\ 76131 Karlsruhe, Germany \\ Full list of author information \\ is available at the end of the \\ article
}

\begin{abstract}
The objective of the present study is to analyse the economic and environmental performance of ATES for a new building complex of the municipal hospital in Karlsruhe, Germany. The studied ATES has a cooling capacity of $3.0 \mathrm{MW}$ and a heating capacity of 1.8 MW. To meet the heating and cooling demand of the studied building, an overall pumping rate of $963 \mathrm{~m}^{3} / \mathrm{h}$ is required. A Monte Carlo Simulation provides a probability distribution of the capital costs of the ATES with a mean value of $1.3 \pm(0.1)$ million $€$. The underground part of the ATES system requires about $60 \%$ of the capital costs and therefore forms the major cost factor. In addition, the ATES is compared with the presently installed supply technology of the hospital, which consists of compression chillers for cooling and district heating. Despite the $50 \%$ higher capital costs of the ATES system, an average payback time of about 3 years is achieved due to lower demand-related costs. The most efficient supply option is direct cooling by the ATES resulting in an electricity cost reduction of $80 \%$. Compared to the reference system, the ATES achieves $\mathrm{CO}_{2}$ savings of about 600 tons per year, hence clearly demonstrating the potential economic and environmental benefits of ATES in Germany.
\end{abstract}

Keywords: Aquifer Thermal Energy Storage (ATES), Shallow geothermal energy, Heating and cooling, Renewable energy, Economic analysis

\section{Introduction}

In regions with moderate climates such as central and northern Europe, Aquifer Thermal Energy Storage (ATES) is a suitable technique to supply buildings with large amounts of heating and cooling. ATES bridges the seasonal mismatch between the ambient temperature and the heating or cooling demand of a building. ATES is an open-loop, bidirectional system, which uses at least one groundwater well in the saturated zone to actively store excess heat in summer and cooling capacity, further named as cold, in winter. The stored thermal energy can be reused when required (Bloemendal et al. 2014; Dickinson et al. 2008; Hähnlein et al. 2010; Kangas and Lund 1994; Nordell et al. 2015; Sommer et al. 2015).

The principle of a bidirectional ATES system is illustrated in Fig. 1. In summertime, cold groundwater stored from winter is extracted from the cold well to cool the building. In most cases, the temperature level is sufficient for direct cooling without the application of a heat pump. However, heat pumps can also be utilised for active cooling. The excess heat of the cooling process is reinjected in the warm well and stored in

(c) The Author(s) 2019. This article is distributed under the terms of the Creative Commons Attribution 4.0 International License (http://creativecommons.org/licenses/by/4.0/), which permits unrestricted use, distribution, and reproduction in any medium, provided you give appropriate credit to the original author(s) and the source, provide a link to the Creative Commons license, and indicate if changes were made. 


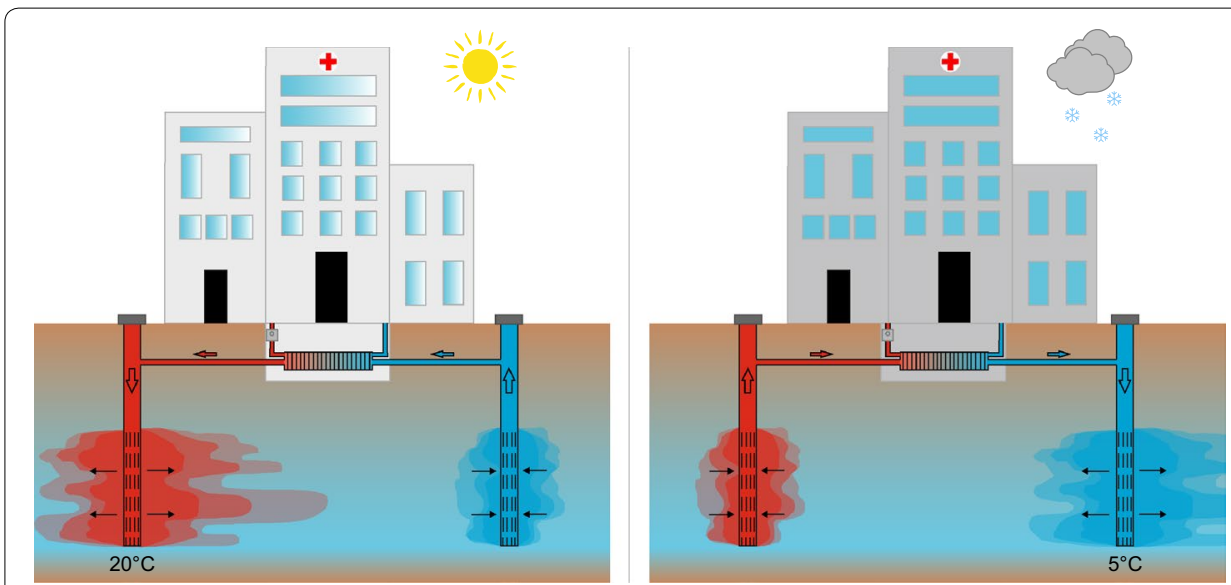

Fig. 1 Operation mode of a doublet ATES system in summer and wintertime including the current temperature threshold for LT-ATES in Germany

the aquifer (Dincer and Rosen 2011; Kalaiselvam and Parameshwaran 2014; Rosen and Koohi-Fayegh 2017).

The reverse process is observed in wintertime by using warm groundwater stored from summer for heating purposes. The temperature level from the aquifer is increased by heat pumps to the required inlet temperature for space heating. The cooled water is reinjected back in the aquifer via the cold well. In an ideal case, a thermal balance is set up in the aquifer after some seasons (Andersson et al. 2013; Bayer et al. 2012; Bloemendal and Olsthoorn 2018; Bridger and Allen 2005, 2010). In some countries and states, a thermal balance is a legal requirement for the operation of ATES (Bloemendal et al. 2014; van Beek and Godschalk 2013).

Most ATES in the Netherlands are shallow and operate with well depths usually ranging between 10 and $150 \mathrm{~m}$ (Bloemendal and Hartog 2018; Fleuchaus et al. 2018). They are classified as low-temperature ATES (LT-ATES) with temperatures $<25^{\circ} \mathrm{C}$. However, in Germany the current temperature threshold for these depths is $20^{\circ} \mathrm{C}$ for heating and $5{ }^{\circ} \mathrm{C}$ for cooling (Fleuchaus et al. 2018; Hähnlein et al. 2010). Worldwide more than 2800 ATES are installed with more than $90 \%$ operating in the Netherlands alone while currently only four ATES exist in Germany (Fleuchaus et al. 2018). ATES is most efficient for buildings with high and constant energy demand over the year, such as offices, airports, universities, shopping malls and in particular hospitals (Bonte et al. 2013; Eggen and Vangsnes 2005; Fleuchaus et al. 2018; Snijders 2005; Sommer et al. 2013; Wigstrand 2009). To implement the technology also beyond the Netherlands, the investment in ATES must result in positive economic effects compared to common and in the future other sustainable supply technologies. However, detailed economic studies about ATES are rarely published (Fleuchaus et al. 2018). In Germany, such techno-economic analyses of the four existing ATES systems are currently not available. Nevertheless, in other countries such studies were recently published and are summarised in Table 1.

Table 1 shows that several feasibility studies have already discussed the economics of ATES considering the capital costs, capacities and payback times. However, the majority of the studies only briefly summarised the economics of ATES. For instance, payback times and reference systems were rarely discussed together with an exception of the 
Table 1 Overview of studies discussing the potential economic benefits of ATES

\begin{tabular}{|c|c|c|c|c|c|c|c|c|}
\hline Author & Country & $\begin{array}{l}\text { Capital } \\
\text { costs (€/ } \\
\text { kW) }\end{array}$ & Purpose & Wells & $\begin{array}{l}\text { Capacity } \\
\text { (MW) }\end{array}$ & $\begin{array}{l}\text { Energy } \\
\text { supply } \\
\text { (MWh) }\end{array}$ & $\begin{array}{l}\text { Payback } \\
\text { time }\end{array}$ & $\begin{array}{l}\text { Reference } \\
\text { system }\end{array}$ \\
\hline $\begin{array}{c}\text { Reilly et al. } \\
\text { (1981) }\end{array}$ & USA & $861^{\mathrm{a}}$ & Heating & 14 & $3-50$ & & & $\begin{array}{l}\text { Electric } \\
\text { boiler and } \\
\text { oil fired } \\
\text { furnace }\end{array}$ \\
\hline $\begin{array}{l}\text { Zimmer- } \\
\text { man and } \\
\text { Drost } \\
(1989)\end{array}$ & USA & $89-890^{a}$ & Cooling & $2-16$ & $2-20$ & & & \\
\hline $\begin{array}{l}\text { Anders- } \\
\text { son and } \\
\text { Sellberg } \\
(1992)\end{array}$ & Sweden & & $\begin{array}{l}\text { Heating } \\
\text { and } \\
\text { cooling }\end{array}$ & & & $\begin{array}{l}1800- \\
10,000\end{array}$ & $2-10$ & \\
\hline $\begin{array}{c}\text { Chant and } \\
\text { Morofsky } \\
\text { (1992) }\end{array}$ & Canada & $133-266^{b}$ & Cooling & & $0.1-10$ & $20-20,000$ & & \\
\hline $\begin{array}{c}\text { van Hove } \\
\text { (1993) }\end{array}$ & $\begin{array}{c}\text { Nether- } \\
\text { lands }\end{array}$ & $1000^{c}$ & Cooling & & 1.5 & & 6 & $\begin{array}{c}\text { Mechanical } \\
\text { cooling }\end{array}$ \\
\hline $\begin{array}{l}\text { Paksoy } \\
\text { et al. } \\
\text { (2009) }\end{array}$ & USA & 750 & Cooling & 6 & 2 & 2025 & & $\begin{array}{l}\text { Standard } \\
\text { chillers }\end{array}$ \\
\hline $\begin{array}{l}\text { Vanhoudt } \\
\text { et al. } \\
\text { (2011) }\end{array}$ & Belgium & 580 & $\begin{array}{l}\text { Heating } \\
\text { and } \\
\text { cooling }\end{array}$ & 2 & 1.2 & 2207 & 8.4 & $\begin{array}{l}\text { Gas boiler } \\
\text { and } \\
\text { cooling } \\
\text { machines }\end{array}$ \\
\hline $\begin{array}{l}\text { Ghaebi } \\
\text { et al. } \\
\text { (2017) }\end{array}$ & Iran & & Cooling & 2 & & 2417 & & $\begin{array}{l}\text { Gas boiler, } \\
\text { compres- } \\
\text { sion } \\
\text { chiller, } \\
\text { ATES }\end{array}$ \\
\hline
\end{tabular}

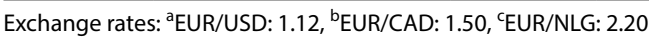

research from Vanhoudt et al. (2011) and Ghaebi et al. (2017). Unfortunately, the evaluation of the economic data is in most cases not transparent or already obsolete. In addition, the applied methods are hardly described and not sufficiently discussed for reconstruction. However, a comprehensive techno-economic and environmental evaluation is indispensable to convince governments and decision makers of the positive impacts of ATES in regions where it is not yet common. Thus, this study focuses on the techno-economic viability and environmental performance of a representative case. The municipal hospital in the city of Karlsruhe, Germany, was faced with the decision of either using LT-ATES or compression chillers for cooling and district heating for a new building complex. Although the geological and hydrogeological framework of the site shows a technical feasibility, the hospital administration finally decided against ATES. One reason for this decision was that the hospital wanted to reinject and store heat above the prescribed limit of $20^{\circ} \mathrm{C}$. However, the local water authorities adhered strictly to this limit. Hospitals in general have a great demand for an efficient and sustainable heating and cooling supply. The average heating demand per patient in German hospitals is $29 \mathrm{MWh}$. This is equivalent to the thermal energy demand of two modern single-detached family houses (Hendriks and Velvis 2012; viamedica 2009). Thus, the current energy supply technology consisting of compression chillers and district heating, further named as reference technology, is compared with the estimated economic performance and energy efficiency of 
ATES over an observation period of 30 years. The sensitivity of the various costs of the ATES components defining the capital costs is determined with a Monte Carlo simulation considering the uncertainties of the input parameters. Furthermore, a sensitivity analysis provides information about the most relevant parameters for the capital costs. The estimated environmental benefits of the studied ATES during operation are illustrated based on the annual $\mathrm{CO}_{2}$ savings per year. Finally, the results of the present study are compared with the economic performance of existing ATES systems.

\section{Materials and methods}

\section{Site}

For the present study, a new building complex of the municipal hospital in Karlsruhe, Germany is considered. The new building with seven floors consists of surgery rooms, intensive care units, normal care and outpatient facilities and is part of the reconstruction measures of the hospital. The completion is scheduled for the year 2020. The load curve for heating and cooling of the building is calculated with RETScreen 4 (Natural Resources Canada 2019) based on the parameters in Table 2 and the climate data of Karlsruhe.

Figure 2 shows the annual load curve of the hospital building for space heating and cooling. The loads are assumed as constant over the observation period and correlate with the ambient temperature of the location. Heating and cooling is required from September to June $\left(t_{H}=2043 \mathrm{~h}\right)$ and from May to October $\left(t_{C}=1558 \mathrm{~h}\right)$, respectively. In the present analysis the ATES system (Fig. 3) and the reference technology provide the entire heating and cooling demand of the building.

\section{Aquifer Thermal Energy Storage (ATES) system}

A conceptual design of the ATES system is essential to assess the economic efficiency and environmental benefits (Bloemendal et al. 2018). Table 3 summarises the considered dimensioning of the ATES system. The volume of pumped groundwater $V$ required for heating and cooling of the building is a key parameter of every ATES system and is calculated as follows:

$$
V=\frac{Q}{c_{w} \cdot \Delta \mathrm{T} \cdot \rho} \cdot 3600
$$

$Q$ is the amount of energy, $c_{w}$ is the volumetric heat capacity of water equal to 4.15 $\left(\mathrm{MJ} / \mathrm{m}^{3} \mathrm{~K}\right), \Delta T$ is the difference between the extracted and injected temperatures, $\rho$

Table 2 Parameters defining the heating and cooling supply of the building

\begin{tabular}{lr}
\hline Parameter & Values \\
\hline Heated floor space $\left(\mathrm{m}^{2}\right)$ & 35,000 \\
Cooled floor space $\left(\mathrm{m}^{2}\right)$ & 41,000 \\
Heating capacity $(\mathrm{kW})$ & 1804 \\
Cooling capacity $(\mathrm{kW})$ & 3080 \\
Space heating power demand $\left(\mathrm{W} / \mathrm{m}^{2}\right)$ & 52 \\
Space cooling power demand $\left(\mathrm{W} / \mathrm{m}^{2}\right)$ & 75 \\
Heating demand $E D_{H}(\mathrm{MWh})$ & 3685 \\
Cooling demand $E D_{C}(\mathrm{MWh})$ & 4800 \\
\hline
\end{tabular}




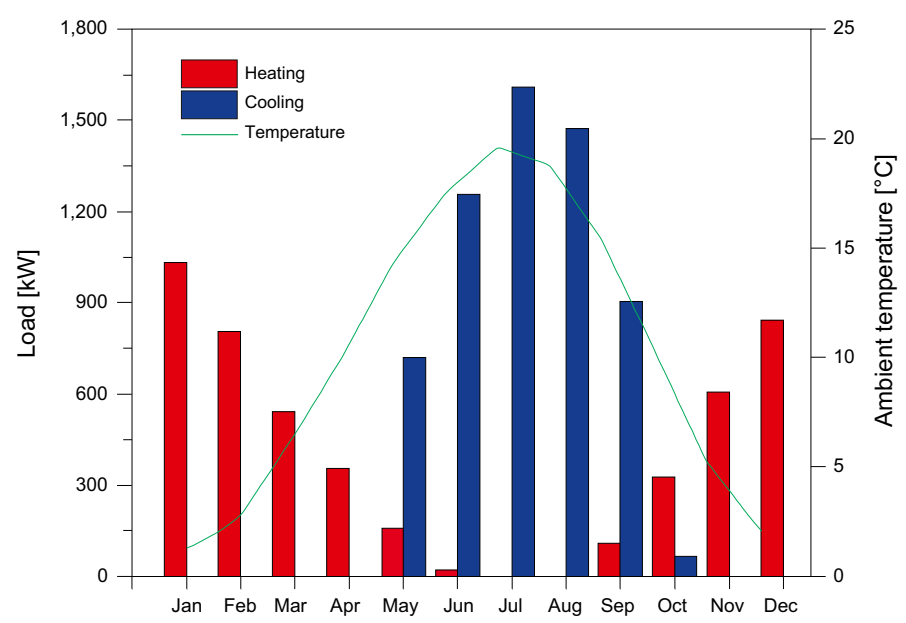

Fig. 2 Annual heating and cooling loads of the building complex and ambient air temperature in Karlsruhe

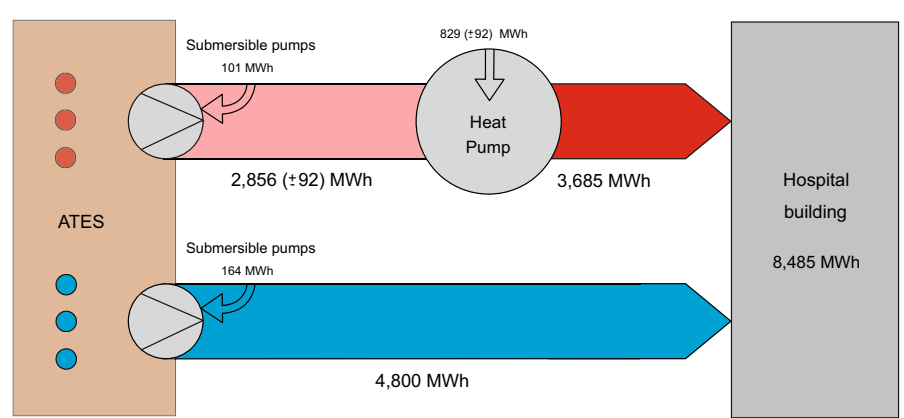

Fig. 3 Energy flows of the considered ATES system for the heating and cooling supply

Table 3 Design parameters of the considered ATES system

\begin{tabular}{llll}
\hline Parameter & Number & Unit & Lifetime (years) \\
\hline Cold well & 3 & - & - \\
Warm well & 3 & - & - \\
Well depth $H$ & 35 & $\mathrm{~m}$ & - \\
Well diameter & 0.8 & $\mathrm{~m}$ & - \\
Screen length $L$ & 30 & $\mathrm{~m}$ & $20-30^{\mathrm{a}}$ \\
Heat Exchanger & 1 & - & $5-7^{\mathrm{b}}$ \\
Submersible pump & 6 & - & - \\
Well distance & $106-318$ & $\mathrm{~m}$ & - \\
$\triangle T$ & 4 & $\mathrm{~K}$ & $20-30^{\mathrm{a}, \mathrm{c}}$ \\
Heat pump & 2 & - & $>30$ \\
ATES & - & - & \\
\hline
\end{tabular}

a VDI 2067 (2012), ${ }^{b} \mathrm{GHJ}(2017),{ }^{\mathrm{C}}$ Bloomquist (2000)

is the water density equal to $1000\left(\mathrm{~kg} / \mathrm{m}^{3}\right)$. The larger $\Delta T$ the higher the energy output from the aquifer to the building resulting in smaller $V$. Depending on the properties, ATES systems achieve $\Delta T$ up to $10 \mathrm{~K}$ (Behi et al. 2014; Vanhoudt et al. 2011). 
However, since the hospital building requires more cooling than heating (Table 1) and the groundwater flow velocity is more than $100 \mathrm{~m} / \mathrm{a}$ at the location a conservative estimation for $\Delta T$ of $4 \mathrm{~K}$ is chosen. Equation 1 delivers the extracted groundwater volume to meet the energy demand of the building which amounts to $614,643 \mathrm{~m}^{3}$ / year for heating and 1,032,999 $\mathrm{m}^{3} /$ year for cooling, on average. The appropriate upper aquifer is dominated by unconsolidated rock, mostly consisting of gravel and sand with a thickness of $35 \mathrm{~m}$. The production and injection wells form the main part of every ATES system and provide access to the aquifer, i.e. groundwater. After Bloemendal and Hartog (2018), the optimal screen length $L$ of a well is a function of the groundwater volume $V$, the volumetric heat capacity of water $c_{w}$ and the aquifer $c_{a}$ equal to $2.8\left(\mathrm{MJ} / \mathrm{m}^{3} \mathrm{~K}\right)$ and is estimated with Eq. 2:

$$
L=\sqrt[3]{\frac{2.25 \cdot c_{w} \cdot V}{c_{a} \cdot \pi}} \approx 1.02 \cdot \sqrt[3]{V}
$$

The required power of the submersible pumps $P$ depends on various parameters and can be calculated by:

$$
P=\frac{q \cdot \rho \cdot g \cdot h}{3.6 \cdot 10^{6}} \cdot \eta^{-1} ; q=\frac{V}{t_{c / h}}
$$

$h$ is the delivery head equal to the well depth, $q$ is the pumping rate, $g$ is the gravity. Due to several factors such as motor and cable losses, the overall pump efficiency $\eta$ is defined as 60\% (Liang and Fleming 2012). Based on Eq. 2 the optimal screen lenghts $L$ for the warm and cold wells is $103 \mathrm{~m}$ and $87 \mathrm{~m}$ in total. Considering the aquifer thickness, a doublet consisting of three warm and three cold fully penetrated wells with a depth $H$ of $35 \mathrm{~m}$ and a diameter of $0.8 \mathrm{~m}$ each is assumed. To ensure that the well screens are always in the saturated zone, a screen length $L$ of $30 \mathrm{~m}$ for each well is chosen. Each well is provided with a submersible pump to pump the groundwater out of the wells to the heat pumps and heat exchangers, respectively (Bakema et al. 1994). Considering the number of wells, $V$ and the heating $t_{H}$ and cooling $t_{C}$ periods, the average pumping rate $q$ of each submersible pump is $100 \mathrm{~m}^{3} / \mathrm{h}$ for heating and $221 \mathrm{~m}^{3} / \mathrm{h}$ for cooling (Eq. 3). To prevent thermal interference, a suitable distance between the warm and the cold wells is assumed based on the thermal radius $R_{t h}$.

$$
R_{t h}=\sqrt{\frac{c_{w} \cdot V}{c_{a} \cdot \pi \cdot L}}
$$

The thermal radii of cold and warm wells are $74 \mathrm{~m}$ and $33 \mathrm{~m}$, respectively (Eq. 4). Thus, a minimum distance of $106 \mathrm{~m}$ is required. However, Dutch authorities ensure a distance of three times the thermal radius between the warm and cold wells (Bloemendal and Hartog 2018). Thus, a distance of $318 \mathrm{~m}$ is also considered. The expected operational lifetime of ATES is more than 30 years (Bloemendal et al. 2014; Hartog et al. 2013; Kalaiselvam and Parameshwaran 2014).

Figure 3 summarises the energy flows of the ATES system for heating and cooling. Depending on the COP of the heat pump, an average of $2856( \pm 92) \mathrm{MWh}$ or $78 \%$ of the 
heating demand, is covered by the thermal energy in the subsurface. The remaining energy is delivered by the heat pump. Since direct cooling is feasible with the ATES system, the amount of cold delivered from the aquifer is equivalent to the cooling demand of the building. As a consequence, the considered ATES has an energy balance ratio between heating and cooling of 0.25. In some European countries such as the Netherlands, the regulations require ATES systems to maintain the thermal balance between heating and cooling. However, this regulation does not yet exist in Germany. Thus, thermal imbalance can be assumed. Based on Eq. $3, t_{C}$ and $t_{H}$, the submersible pumps have an total electricity demand of $265 \mathrm{MWh}$ for heating and cooling.

\section{Capital costs of ATES system}

The parameters used to determine the capital costs of the ATES system $C_{A T E S}$ are not sitespecific, which means they have a strong variability. Some component costs, such as that for the heat exchanger are derived from literature (Seider 2006; Vanhoudt et al. 2011). Others, are used from comparable shallow geothermal projects or from service catalogues (GHJ 2017; GWE 2017; LANUV 2015). In this case, an accurate and deterministic calculation of the capital costs is not feasible. Thus, a Monte Carlo Simulation with 100,000 iterations quantifies the uncertainty of each parameter. The simulation and the sensitivity analysis are both carried out with the software @Risk (version 7.5) (Palisade 2019). For every parameter, a symmetric triangular distribution bounded by a minimum, mode and maximum value is used. The most likely value is the mode while towards the minimum and maximum values the probability decreases continuously. In the present simulation, the minimum and maximum values are the best (cheapest) and worst-case (most expensive) scenarios. In addition, a sensitivity analysis determines the components with the strongest influence on the capital costs. A sensitivity analysis delivers an insight into the structure of an investment and indicates the impacts of its uncertainties (Blohm et al. 1995). Table 4 summarises minimum, mode and maximum values for each component of the ATES system used for the Monte Carlo Simulation and the sensitivity analysis.

\section{Current costs of ATES system}

The current costs of the ATES system $C C_{A T E S}$ include the demand-related costs $D C$ and the operation-related costs $O C$, derived from the German technical guideline VDI 2067 (2012). The demand-related costs are made up by the costs for the heating $\mathrm{CH}$ and cooling $\mathrm{CCO}$ supply (Eqs. 5 and 6). The operation-related costs comprise of the costs for maintenance $M$ and replacement $R$ of components within the lifetime of the ATES system.

$$
\begin{aligned}
& C C_{A T E S}=D C+O C=C H+C C O+M_{A T E S}+R_{A T E S} \\
& C C_{A T E S}=\frac{E D_{H}}{C O P_{H P}} \cdot E C+P \cdot t_{H} \cdot E C+P \cdot t_{C} \cdot E C+C_{A T E S} \cdot M_{A T E S}+R_{A T E S}
\end{aligned}
$$

The electricity costs $E C$ are site-specific costs of the hospital, while the $\mathrm{COP}_{\mathrm{HP}}$ is a generic value from literature (Table 5). The costs for heating are composed of the electricity costs $E C$ to drive heat pumps and the submersible pumps. For direct cooling the use of heat pumps is not required, therefore only electricity costs $E C$ to power the submersible pumps (Eqs. 3 and 6) are considered. The costs for maintenance are defined as a certain 
Table 4 Minimum, mode and maximum values for the Monte Carlo Simulation of the $\mathrm{C}_{\mathrm{ATES}}$

\begin{tabular}{|c|c|c|c|c|}
\hline Category & Component & Minimum $(€)$ & Mode $(€)$ & Maximum $(€)$ \\
\hline \multirow{4}{*}{$\begin{array}{l}\text { Pre-investigation/ } \\
\text { Feasibility }\end{array}$} & Site inspection ${ }^{a}$ & 50 & 1216 & 2382 \\
\hline & Construction schedule ${ }^{a}$ & 5 & 846 & 1687 \\
\hline & Feasibility study ${ }^{b}$ & 3939 & 22,488 & 41,037 \\
\hline & Design planning ${ }^{c}$ & 6200 & 47,706 & 89,212 \\
\hline \multirow[t]{7}{*}{ Preparation } & Site equipment ${ }^{a, d}$ & 1738 & 7319 & 12,900 \\
\hline & Transport drilling rige & 767 & 4701 & 8636 \\
\hline & Movement drilling riga, d & 300 & 7950 & 15,600 \\
\hline & Sampling \& core boxes ${ }^{\mathrm{a}, \mathrm{d}}$ & 924 & 9114 & 17,304 \\
\hline & Bore log \& drilling profile $e^{a, e}$ & 539 & 803 & 1066 \\
\hline & $\begin{array}{l}\text { Clear washing \& pressure } \\
\text { washing }^{d}\end{array}$ & 31,592 & 36,706 & 41,820 \\
\hline & Pumping tests ${ }^{\mathrm{a}}$ & 26,338 & 35,319 & 44,300 \\
\hline Drilling & Well drilling ${ }^{f}$ & 24,780 & 90,825 & 156,870 \\
\hline \multirow[t]{13}{*}{ Well piping and well installation } & Filter pipe $e^{a, d, e}$ & 35,250 & 48,375 & 61,500 \\
\hline & Solid wall pipe $e^{e}$ & 14,160 & 30,881 & 47,602 \\
\hline & Centering ${ }^{\mathrm{d}, \mathrm{e}}$ & 24 & 102 & 180 \\
\hline & Bottom cap ${ }^{\mathrm{a}}$ & 48 & 480 & 912 \\
\hline & Well head ${ }^{\mathrm{a}}$ & 1166 & 18,313 & 35,460 \\
\hline & Water chamber ${ }^{\mathrm{a}, \mathrm{e}}$ & 40,800 & 46,305 & 51,810 \\
\hline & Shaft cover ${ }^{a, d}$ & 767 & 2934 & 5100 \\
\hline & Filter gravel/sand ${ }^{\mathrm{a}}$ & 826 & 21,293 & 41,760 \\
\hline & Counter filter ${ }^{a}$ & 28 & 464 & 900 \\
\hline & Clay seal ${ }^{\mathrm{a}, \mathrm{d}}$ & 2687 & 63,077 & 123,467 \\
\hline & Submersible pumps ${ }^{d}$ & 15,570 & 21,585 & 27,600 \\
\hline & Stand pump ${ }^{d, g}$ & 25,200 & 30,823 & 36,446 \\
\hline & Well connections ${ }^{\mathrm{a}}$ & 1204 & 52,298 & 103,392 \\
\hline \multirow[t]{8}{*}{ Controlling \& Monitoring } & Electronic switchboard ${ }^{\mathrm{a}}$ & 2213 & 50,982 & 99,750 \\
\hline & Water flowmeter ${ }^{\mathrm{a}, \mathrm{f}}$ & 893 & 9105 & 17,316 \\
\hline & Pump control system, ${ }^{a, e}$ & 1779 & 48,350 & 94,920 \\
\hline & Site equipment monitoring well ${ }^{\mathrm{a}, \mathrm{e}}$ & 2100 & 11,550 & 21,000 \\
\hline & $\begin{array}{l}\text { Movement drilling rig monit. } \\
\text { well } l^{\mathrm{a}, \mathrm{e}}\end{array}$ & 162 & 925 & 1687 \\
\hline & Drilling monitoring wells $s^{\mathrm{a}, \mathrm{e}}$ & 2057 & 30,729 & 59,400 \\
\hline & Control line $e^{d}$ & 15,000 & 20,000 & 25,000 \\
\hline & Electricity connection ${ }^{d}$ & 35,000 & 55,000 & 75,000 \\
\hline \multirow[t]{2}{*}{ Piping } & Horizontal piping ${ }^{d}$ & 189,815 & 331,988 & 474,161 \\
\hline & Pressure washing ${ }^{d}$ & 7161 & 8638 & 10,115 \\
\hline \multirow[t]{2}{*}{ Building integration } & Heat pump ${ }^{g}$ & 11,456 & 41,365 & 71,274 \\
\hline & Heat exchanger ${ }^{h, i}$ & 65,600 & 67,800 & 70,000 \\
\hline
\end{tabular}

Each single cost item is summarised in seven different categories

a LANUV (2015), b MacKenzie and Cusworth (2007), 'Chiasson and Culver (2006), 'dGH (2017), 'LANUV (2004/2005),

fSanderson (2018, personal communication), ${ }^{9} \mathrm{GWE}$ (2017), hSeider (2006), 'Vanhoudt et al. (2011)

percentage of the $C_{A T E S}$. The observation period is defined as 30 years; however some components such as the submersible pumps or the heat pumps have a shorter lifespan and have to be replaced within the observation period (Table 3). Table 5 provides an overview of the parameters defining the current costs $C C_{A T E S}$. 
Table 5 Input parameters to calculate the current costs of the ATES system

\begin{tabular}{|c|c|c|c|}
\hline Parameter & Minimum & Mode & Maximum \\
\hline COP heat pump COP & 4 & 4.5 & 5 \\
\hline Electricity costs $E C(\mathrm{ct} / \mathrm{kWh})^{c}$ & 16 & 16.5 & 17 \\
\hline Maintenance $M_{\text {ATES }}(\%)^{d}$ & - & 4 & - \\
\hline Replacement $R_{\text {ATES }}$ & & Table 2 & \\
\hline Heating period $t_{H}(h)$ & & 2043 & \\
\hline Cooling period $t_{C}(h)$ & & 1558 & \\
\hline
\end{tabular}

a Boissavy (2015), ${ }^{\text {b }}$ International Energy Agency (2007), ' Stindl (2017, personal communication) ${ }^{\mathrm{d}}$ Sommer et al. (2015)

Table 6 Parameters defining the capital and current costs of the district heating supply

\begin{tabular}{|c|c|c|c|c|c|}
\hline Category & Parameter & Minimum & Mode & & Maximum \\
\hline \multirow[t]{4}{*}{ Capital costs $C_{D H}$} & Excavation work $(€ / m)$ & $101.15^{\mathrm{a}}$ & 113.05 & & $124.95^{b}$ \\
\hline & Piping $(€ / m)$ & $232.05^{b}$ & 431.40 & & $630.70^{c}$ \\
\hline & Contingency (\%) & & $10^{d}$ & & \\
\hline & & Karlsruhe & $U \operatorname{lm}^{f}$ & Pforzheim ${ }^{g}$ & Emmendingen $^{\mathrm{h}}$ \\
\hline \multirow[t]{5}{*}{ Current costs } & Commodity price CP (ct/kWh) & 5.87 & 5.90 & 8.96 & 8.94 \\
\hline & Power price $P P(€ / \mathrm{kW})$ & 35.16 & 50.54 & 18.72 & 23.80 \\
\hline & Basic price $B P(€)$ & 191.00 & 558.00 & - & 257.04 \\
\hline & Efficiency for consumer $\eta_{D H}(\%)^{i}$ & 98 & & & \\
\hline & Maintenance $(\%)^{j}$ & 1 & & & \\
\hline
\end{tabular}

a Stadtwerke Sindelfingen (2007), b(2018), 'Stadtwerke Waldkraiburg (2018), dHallamICS (2012), e'Stadtwerke Karlsruhe (2018), ${ }^{\mathrm{f}}$ Stadtwerke Ulm (2018), ' ${ }^{9}$ Stadtwerke Pforzheim (2019), 'h Stadtwerke Emmendingen (2019b), 'Gudmundsson et al. (2013), ${ }^{\mathrm{j}}$ Konstantin (2017)

\section{Reference technology}

In Karlsruhe, a widespread district heating network $(180 \mathrm{~km})$ exists fed with over $770 \mathrm{GWh}$ of heat. This network is mostly supplied by industrial waste heat of a large mineral oil refinery (MiRo) and by combined heat and power generation (CHP) of a steam power plant and is being expanded further (Stadtwerke Karlsruhe 2017). The mineral oil refinery itself currently supplies over 30,000 homes in Karlsruhe. The hospital is already connected to the district heating network of Karlsruhe including substations. Thus, only costs for maintenance and pipe construction from the heating centre to the building collected from different district heating providers are considered (Table 6). The maintenance costs depend on the capital costs defined as the costs for pipe constructions. The distance between the heating centre and the building is $100 \mathrm{~m}$. The demand-related cost for district heating $D C_{D H}$ depend on the consumption of the end user and are calculated with Eq. 7 based on the parameters of Table 6. $C P, P P$ and $B P$ are derived from the municipal utility of Karlsruhe and for comparison of three surrounding cities in Baden-Württemberg (Table 6).

$$
D C_{D H}=C P \cdot\left(E D_{H} \cdot \eta_{D H}\right)+P P+B P
$$

The municipal hospital uses magnetic bearing compression chillers for cooling. These specific types of chillers are frequently used in hospitals and data centres and are therefore representative for a standard cooling supply technology (Engie 2018). Given the required cooling capacity of $3080 \mathrm{~kW}$, the estimated capital costs $C_{C C H}$ of the compression chillers range between $125 € / \mathrm{kW}$ and $200 € / \mathrm{kW}$ (Institut für Energie- und 
Umwelttechnik 2002; Schäfer and Negele 2009; Schlott 2001). The costs for the feasibility study, development and engineering are defined as a certain percentage of the capital costs (Table 7). The current costs of the compression chillers $C C_{C C H}$ depend on the energy demand of the system and are composed of the $\mathrm{COP}_{\mathrm{CCH}}$, the electricity costs $E C$ and the cost for maintenance $M_{C C H}$ and replacement $R_{C C H}$ (Eq. 8 and Table 7).

$$
C C_{C C H}=\frac{E D_{C}}{C O P_{C C H}} \cdot E C+C_{C C H} \cdot M_{C C H}+R_{C C H}
$$

The recommended depreciation period of a compression chiller is 15 years resulting in a replacement investment within the observation period of 30 years VDI 2067 (2012).

\section{Economic efficiency}

The costs for electricity and district heating are both subject to an annual price increase based on the generic trend of the recent years in Germany. For electricity costs, a factor of $2.7 \%$ is considered and for district heating an annual price increase of $0.5 \%$ is chosen (Bundesministerium für Wirtschaft und Energie 2017). For comparison, all current costs are discounted with an interest factor to the beginning of the observation period. The interest factor $q^{T}$ is calculated with Eq. 9:

$$
\frac{1}{q^{T}}=\frac{1}{(1+i)^{T}}
$$

$T$ is the payment date with $T \geq 0 . T=0$ being the beginning of the investment of both technologies. The discount rate, defined as $i$, is set at $5 \%$. The net present value $N P V$ of the investment is defined as the present value of the net payments of an investment at the time $t=0$. The $N P V$ is calculated from the sum of the present value of all revenues and the present value of all expenses within the observation period (Konstantin 2017). In the present study, the revenues are the total costs of the reference technology, while the expenses are the total costs of the ATES system (Fig. 4).

\begin{tabular}{|c|c|c|c|}
\hline Parameter & Minimum & Mode & Maximum \\
\hline Capital costs $C_{\mathrm{CCH}}(€ / \mathrm{kW})^{\mathrm{a}, \mathrm{b}, \mathrm{c}}$ & 125 & 163 & 200 \\
\hline Feasibility (\%) ${ }^{d}$ & & 2.3 & \\
\hline Development (\%) & & 3 & \\
\hline Engineering $(\%)^{f}$ & & 5 & \\
\hline Contingency (\%) & & 10 & \\
\hline COP compression chiller COP $\mathrm{CCH}_{\mathrm{C}}^{\mathrm{b} g}$ & 5 & 6 & 7 \\
\hline Maintenance $M_{\mathrm{CCH}}(\%)^{h}$ & & 4 & \\
\hline Electricity costs EC (ct/kWh) ${ }^{i}$ & 16 & 16.5 & 17 \\
\hline Lifespan $\left(\right.$ years) $^{j}$ & & 15 & \\
\hline
\end{tabular}
The $N P V$ is calculated with Eq. 10

${ }^{a}$ Institut für Energie- und Umwelttechnik (2002), ${ }^{b}$ Schäfer and Negele (2009), ${ }^{\circ} S c h l o t t ~(2001),{ }^{d}$ MacKenzie and Cusworth (2007), ${ }^{e}$ Queensland Government (2015), ${ }^{\mathrm{f} C h i a s s o n}$ and Culver (2006), ${ }^{9}$ Engie (2016), ${ }^{\mathrm{h}}$ Heinrich et al. (2014), ${ }^{\mathrm{i}}$ Stindl (2017, personal communication, $)^{j} \mathrm{VDI} 2067$ (2012) 


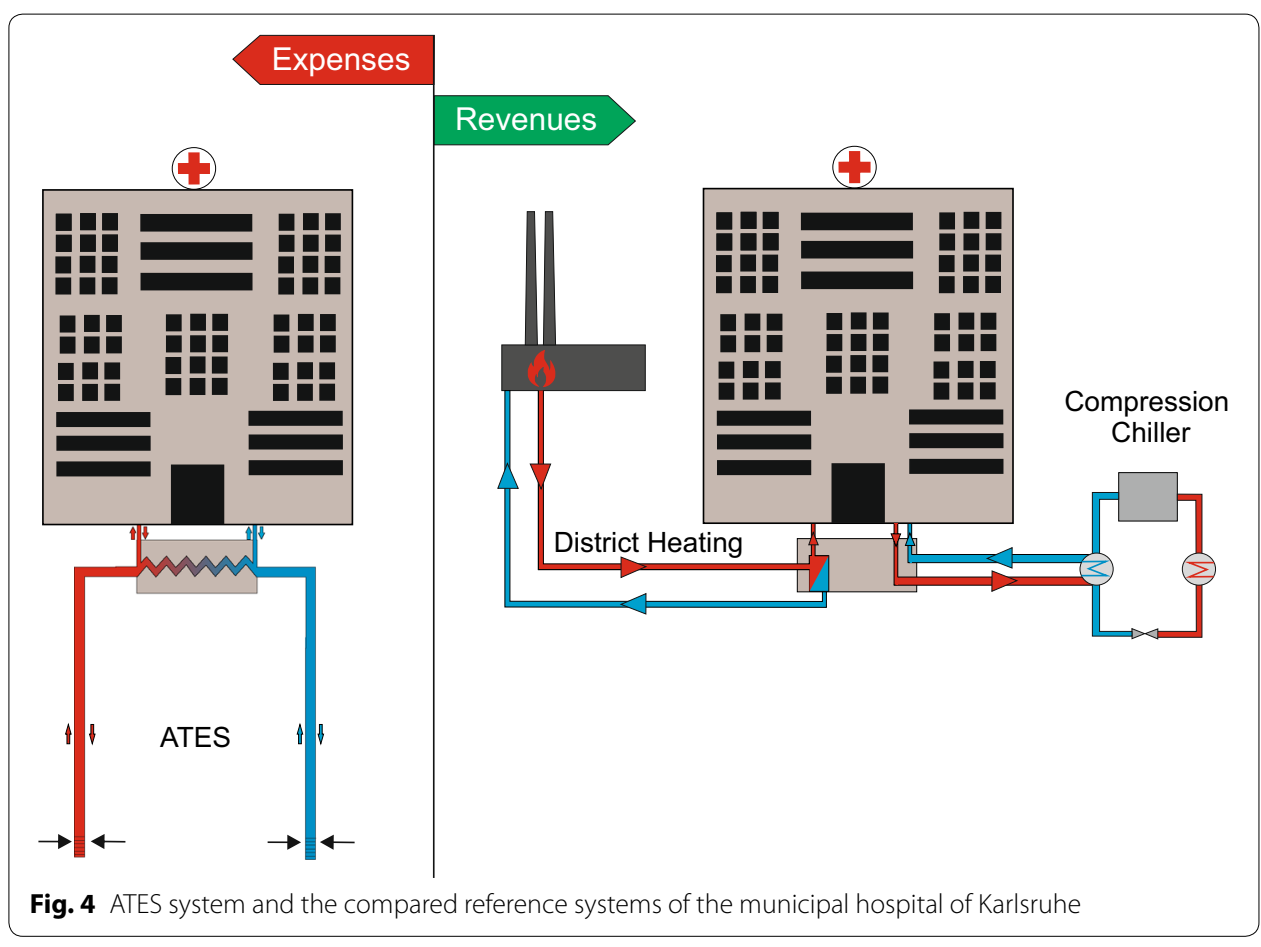

$$
N P V=-C_{A T E S}+\sum_{t=1}^{T} R_{t} \times q^{-1}
$$

$C_{\text {ATES }}$ are the capital costs of the ATES, $R_{t}$ is the return at the time $t$, which results from the difference between the current costs of the ATES system and the reference technology. The investment in an ATES system is beneficial towards the investment in the reference technology if the net present value of the ATES system is positive.

\section{Environmental analysis}

The environmental analyses of the ATES system and the reference technology are based on their annual $\mathrm{CO}_{2}$ emissions $C E$ caused by operation. The particular $\mathrm{CO}_{2}$ emissions are calculated with Eqs. 11 and 12.

$$
\begin{aligned}
& C E_{A T E S}=E_{A T E S} \cdot E F_{e l} \\
& C E_{r e f}=E_{C C H} \cdot E F_{e l}+E D_{D H} \cdot E F_{D H}
\end{aligned}
$$

Here $E$ is the annual electricity consumption of the particular technologies and $E D_{D H}$ is the district heating demand based on $E D_{H}$ and $\eta_{D H} . E F_{e l}$ and $E F_{D H}$ are the emissions factors for electricity and district heating, summarised in Table 8. 
Table $8 \mathrm{CO}_{2}$ emission factors for district heating and electricity

\begin{tabular}{llll}
\hline $\mathrm{CO}_{\mathbf{2}}$ emission factor & Minimum & Mode & Maximum \\
\hline Electricity $(\mathrm{t} / \mathrm{MWh})^{\mathrm{a}, \mathrm{b}}$ & 0.357 & 0.417 & 0.476 \\
District heating $(\mathrm{t} / \mathrm{MWh})^{\mathrm{b}, \mathrm{c}}$ & 0.068 & 0.10 & 0.24
\end{tabular}

${ }^{\mathrm{a}}$ EnbW (2017), ${ }^{\mathrm{b}}$ Stadtwerke Karlsruhe (2017), ${ }^{\mathrm{C}}$ Fair Energy (2018)

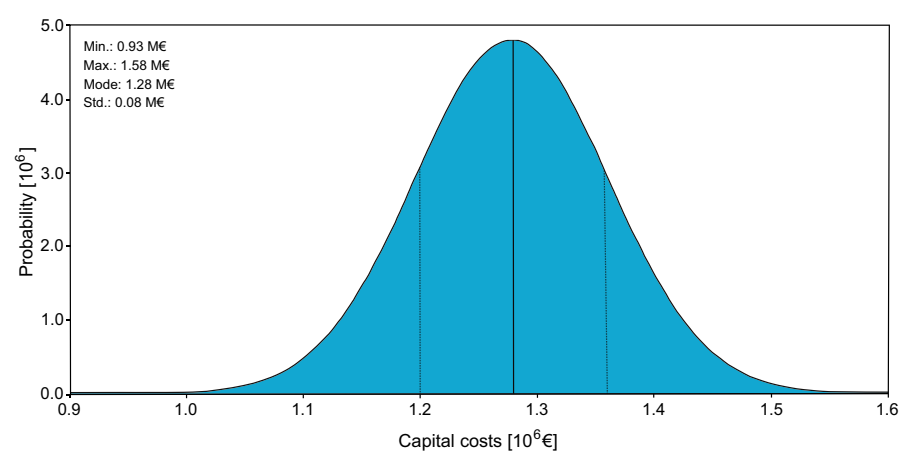

Fig. 5 Probability distribution of the capital costs of the studied ATES system

\section{Results and discussion}

\section{Capital costs of the ATES system}

The result of the Monte Carlo Simulation for the capital costs of the ATES system after 100,000 iterations is presented in Fig. 5, showing a normal distribution with a mean value of $1.285( \pm 0.08)$ million $€$.

The major cost factor of about $60 \%$ is associated with the underground part consisting of six wells, pipes and groundwater measuring points. The part of the ATES system above the ground includes the building integration (heat pumps and heat exchanger) and contributes to $23 \%$ of the capital costs. The remaining $15 \%$ of the capital costs belong to the pre-investigations and the construction site installation. The capital costs are dominated by well piping and well installation (Fig. 6). The pricing level is dependent on the service provider and the quality of the installed components. Higher costs for well piping and installation could increase the capital costs by more than $10 \%$. Thus, the planner of an ATES system should carefully choose the components for the implementation of the wells (Table 4) according to actual requirements. Controlling and monitoring are also a significant factor when taking into account the capital costs. Accurate monitoring is crucial to assure an efficient, long-term operation of an ATES system (Kalaiselvam and Parameshwaran 2014). The building integration, including heat pumps and heat exchanger, is less sensitive to the capital costs. However, the performance of the heat pump is particularly significant to the efficiency of the ATES system and therefore to the current costs (see "Comparison" section).

\section{Comparison}

The ATES system and the reference system differ in terms of their cost structures as illustrated in Fig. 7. The ATES system is the more capital-cost-intensive technology with 


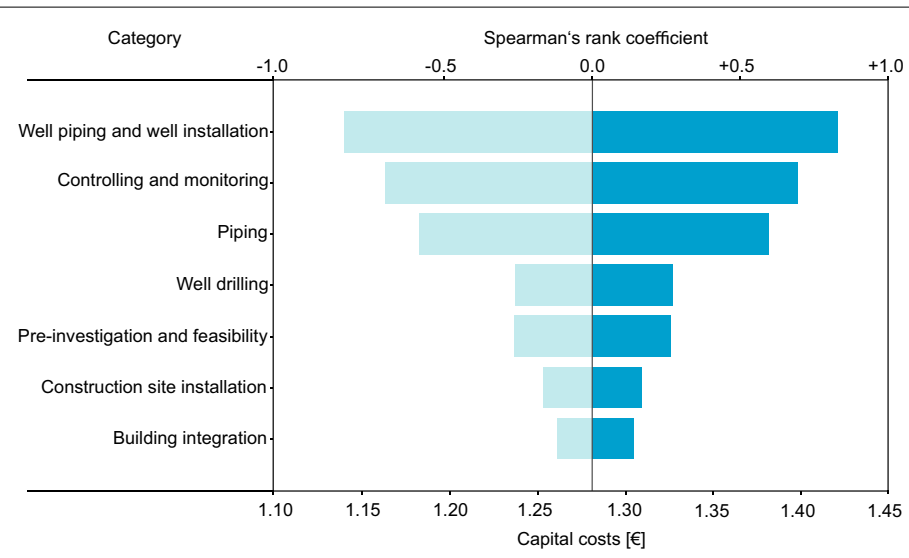

Fig. 6 Spearman's rank coefficients representing the degree of correlation between the input parameters of the different categories to the variance of the capital costs. The relative importance of the single categories of the ATES system on the capital costs is also illustrated

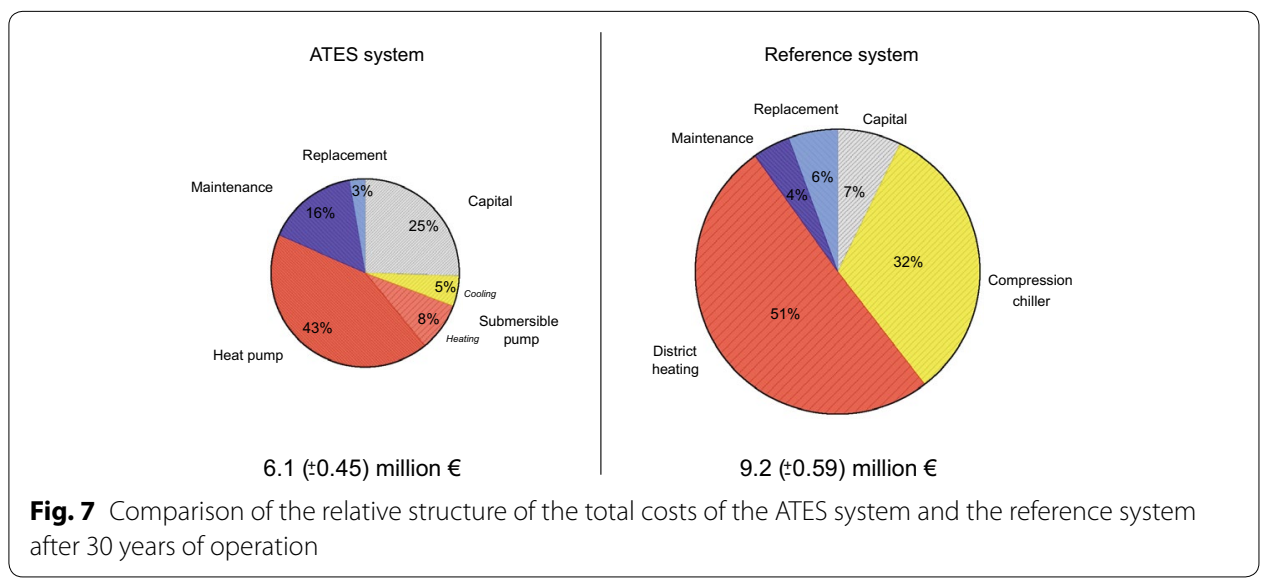

one-quarter of the total costs made up by the capital. For both systems, the largest portion of the total costs is attributed to the heating supply of the building. The difference being that the heat pumps and submersible pumps of the ATES system operate with electricity and the reference system uses district heating with coal and crude oil as primary energy source. The electricity consumption of the heat pump, defined by the COP, is the most significant parameter regarding the cost-effectiveness of the ATES system. Figure 7 clearly shows a substantial difference between the electricity costs for cooling. The operation of the submersible pumps of the ATES system represents only $5 \%$ of the total costs, while the electricity costs for the compression chillers of approximately $30 \%$ are the second largest for the reference system. The maintenance of the ATES system requires more effort and strongly depends on the number of wells and the hydrochemical conditions of the aquifer (Hähnlein et al. 2013).

Figure $8 \mathrm{a}-\mathrm{c}$ compare the capital and current costs of the ATES system and the reference technology of the hospital over an observation period of 30 years. The comparison is carried out for the ATES operating as a hybrid system as well as for cooling and heating purposes only. The beginning of the investment is the year zero. The estimated 

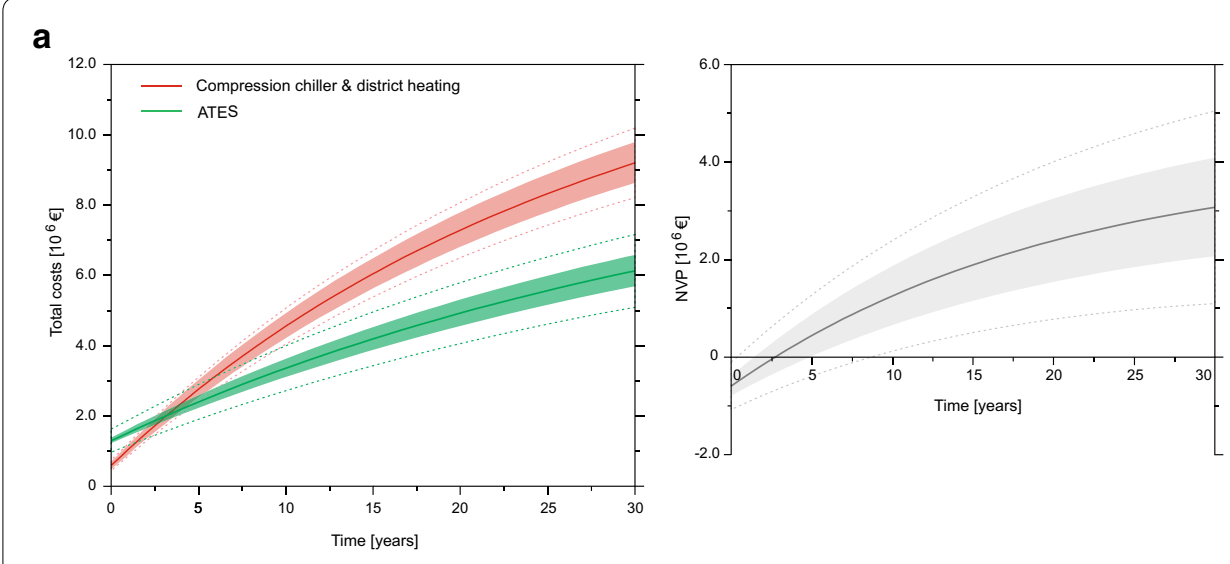

b
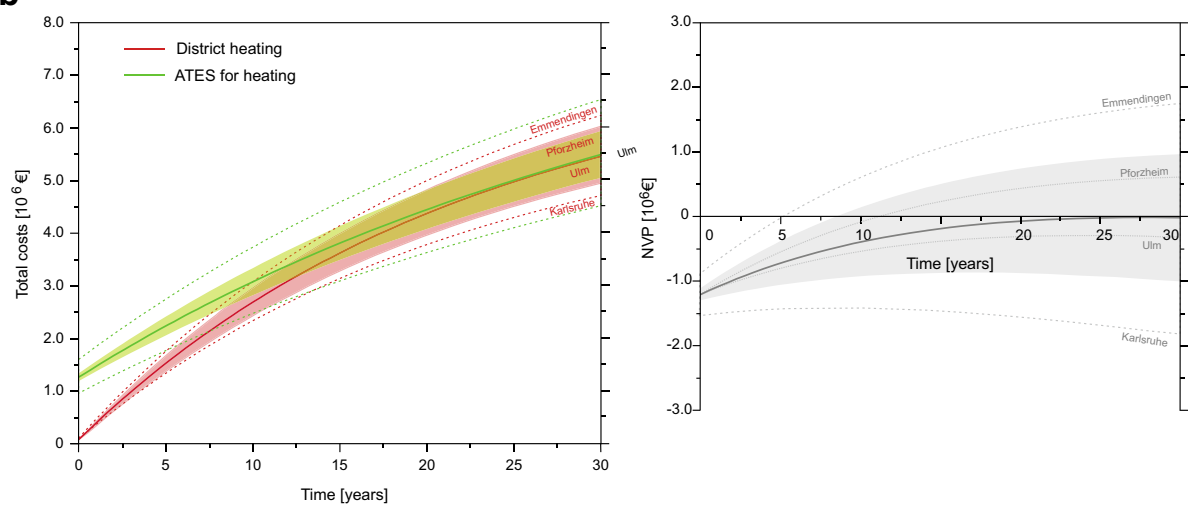

C
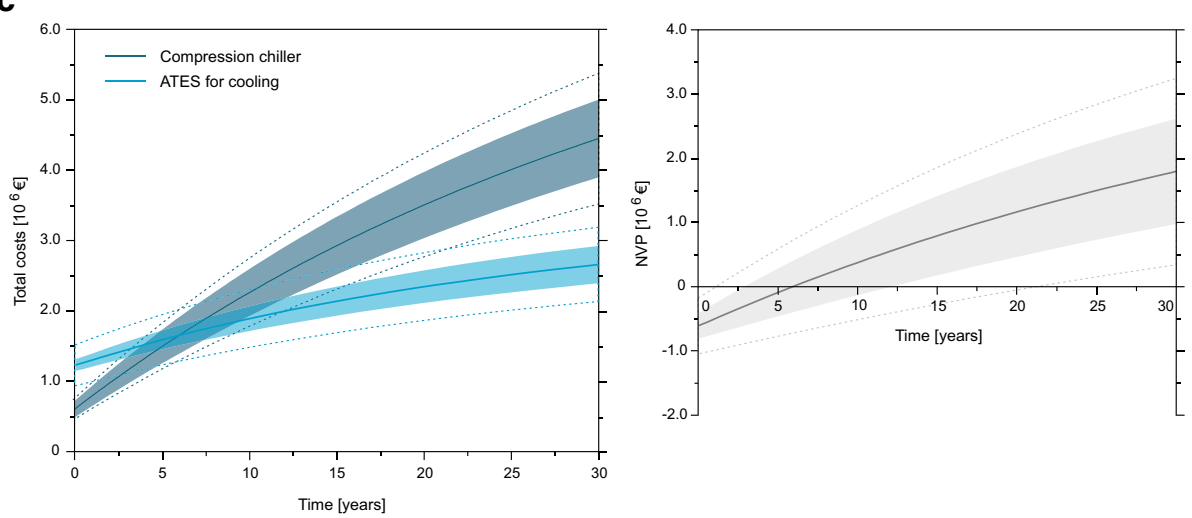

Fig. 8 a Economic analysis of the ATES operating as hybrid system and the reference technologies over the observation period of 30 years divided into total costs and the NPV of the ATES system; $\mathbf{b}$ comparison of the total costs for the ATES system only for the heating supply of the building compared with district heating; $\mathbf{c}$ specifically compares the total costs for the direct cooling supply by the ATES system and the compression chillers

capital costs of the reference technology are $667,000( \pm 119,000) €$ which is about $50 \%$ lower than the capital costs of the ATES system. The expected additional specific capital costs for the ATES system amount to $192( \pm 12) € / \mathrm{kW}$. This is consistent with the range given by Chant and Morofsky (1992) for higher specific capital costs of ATES systems, which is between $130 € / \mathrm{kW}$ and $265 € / \mathrm{kW}$, compared to common supply technologies. 
The implementation of ATES potentially leads to mean energy savings of $3500 \mathrm{MWh}$ or $76 \%$ compared to the reference technology. An average COP of 28.5 for the subsurface installation of the ATES is calculated. Despite higher capital costs, the expected NPV of the hybrid ATES is $3.1( \pm 1.0)$ million $€$ after 30 years (Fig. 8a). Thus, the investment in the ATES system is rather positively evaluated in comparison to the reference technology. The estimated saved amount of energy corresponds to the heating demand of 240 modern single-family houses or 120 hospital beds. Due to the lower energy consumption, a potential average payback time of 2.7 years is achieved. The main reason for the positive economics of the ATES system is direct cooling in summertime, which is the cheapest supply option. Compared to the compression chillers the expected annual demand-related costs are reduced by $109,000 €$ and $80 \%$, respectively (Table 9 and Fig. 8c). Thus, the ATES system is most suitable for buildings with a large cooling demand such as hospitals or data centres.

The estimated average seasonal performance factor (SPF) of the ATES system for heating is four and mainly influenced by the efficiency of the heat pumps. Since the hospital already has access to the district heating network of Karlsruhe, the economic burden of the capital costs and maintenance in relation to district heating, is relatively low. In contrast, the ATES system has extra costs for maintenance and replacement (Fig. 7, Table 9). The expected demand of district heating is over four times higher than the electricity demand of the ATES system for heating. This leads to potential mean energy cost savings of 179,000 $€$ per year (Table 9). However, the economic benefit of ATES for heating is not always given due to the estimated low capital costs for district heating in the present case (see Fig. 8b). Thus, direct cooling provides most of the economic benefit of the ATES compared to the reference technology.

Table 6 and Fig. 8b show a large variation of the demand-related costs for district heating. Depending on region and provider, the district heating costs range between $285,000 €$ and $379,000 €$ for the same heating demand of 3685 MWh only in the state of Baden-Württemberg. Since the district heating network of Karlsruhe is partially supplied by industrial waste heat of the MiRO (57\%), the city has a significant site-specific advantage. Consequently, the price for district heating is up to $25 \%$ less than in other regions, deeming the ATES system for heating uneconomical in Karlsruhe (Fig. 8b). However, the situation is the opposite in the city of Emmendingen where the district

Table 9 Summary of the estimated average capital and current costs and energy consumption of the ATES system and the reference technology

\begin{tabular}{|c|c|c|c|c|}
\hline & \multicolumn{2}{|l|}{ ATES system } & \multicolumn{2}{|c|}{ Reference technology } \\
\hline & ATES heating & ATES cooling & $\begin{array}{l}\text { Compression } \\
\text { chillers }\end{array}$ & District heating \\
\hline Capital costs $(k €)$ & 1259 & & 607 & 60 \\
\hline Electricity consumption (MWh) & 930 & 164 & 823 & - \\
\hline District heating consumption (MWh) & - & - & - & 3758 \\
\hline Electricity costs $(\mathrm{k} €)$ & 153 & 27 & 136 & - \\
\hline District heating costs $(k €)$ & - & - & - & 332 \\
\hline Maintenance $(k €)$ & 50 & & 24 & 0.6 \\
\hline Replacements (k€) & 8.5 & & 33.0 & - \\
\hline
\end{tabular}


heating network is supplied by power plants operating with natural gas and wood chips (Stadtwerke Emmendingen 2019a). For this reason, the costs for district heating per year are almost 100,000 $€$ higher than in Karlsruhe for the same heating demand of the hospital. Thus, the ATES system for heating shows a payback time of 5 years in Emmendingen. It is important to note that the district heating costs can vary greatly even within small distances. Hence, it is essential to conduct a detailed cost analysis of the reference technology particularly for locations where district heating is used. Another aspect is the future planning reliability with regard to the demand-related costs of the heating supply. The price for district heating can change rapidly within a short period of time. For example, in the city of Ulm, Germany, the commodity price for district heating varied by $27 \%$ in 1 year alone. Consequently, the economic planning of the future heat supply via district heating is more challenging than for systems driven by electricity. In general, ATES systems and heat supply via district heating do not automatically exclude each other. The city of Neubrandenburg, Germany integrated an ATES system in a district heating network. Here the waste heat of a power plant is stored in summertime and reinjected into the district heating network in wintertime to supply residential areas (Kabus et al. 2009). This special usage is only possible for high temperature ATES (HT-ATES) systems. Greater well depths ensure higher storage loading temperatures $\left(\right.$ e.g. $90^{\circ} \mathrm{C}$ ), which can supply district heating networks in Germany, typically operating with temperatures above $20^{\circ} \mathrm{C}$ (Sanner 2000).

\section{Comparison with realised ATES systems}

The estimated specific capital costs of the considered ATES system in the present study are $416( \pm 27) € / \mathrm{kW}$ (Fig. 9). The present value is consistent with the specific capital costs of various Dutch ATES systems ranging between $1600 € / \mathrm{kW}$ for small and $200 € /$ $\mathrm{kW}$ for large systems (Snijders and van Aarssen 2003). Since the present ATES is classified as a medium-sized system (Table 2) after Fleuchaus et al. (2018), the results of previous investigations, showing a decrease of the specific capital costs with increasing size can therefore be confirmed (Paksoy et al. 2009; Snijders and van Aarssen 2003). Thus, it can be stated that the Monte Carlo Simulation is an appropriate method to estimate the capital costs of an ATES systems. However, most of the specific capital costs of the 14 ATES systems (0.43-20 MW) in Fig. 9 are higher. In addition, Fig. 9 does not show the relation between decreasing specific capital costs and increasing capacity, which is due to several reasons. Some ATES of Fig. 9 were built together with scientific partners during research projects with less focus on the economics (Agassiz, New Jersey, Utrecht, Eindhoven). Others are integrated in district heating networks (Neubrandenburg), resulting in deeper wells. The high sensitivity of the well construction to the capital costs (Fig. 6) is therefore also derivable from Fig. 9. For instance, the ATES for heating and cooling of the Copenhagen airport has specific capital costs of $1600 € / \mathrm{kW}$, which could result from the rather large depths of $110 \mathrm{~m}$ of 10 installed wells (Baxter et al. 2018; Larsen and Petersen 2015).

The expected average payback time of 2.7 years of the present study is less than the estimated average payback time of 7 years of the 16 ATES illustrated in Fig. 9. However, it is important to mention that the payback times in the literature are often discussed without mentioning the reference technology. Some of the ATES in Fig. 9 with 

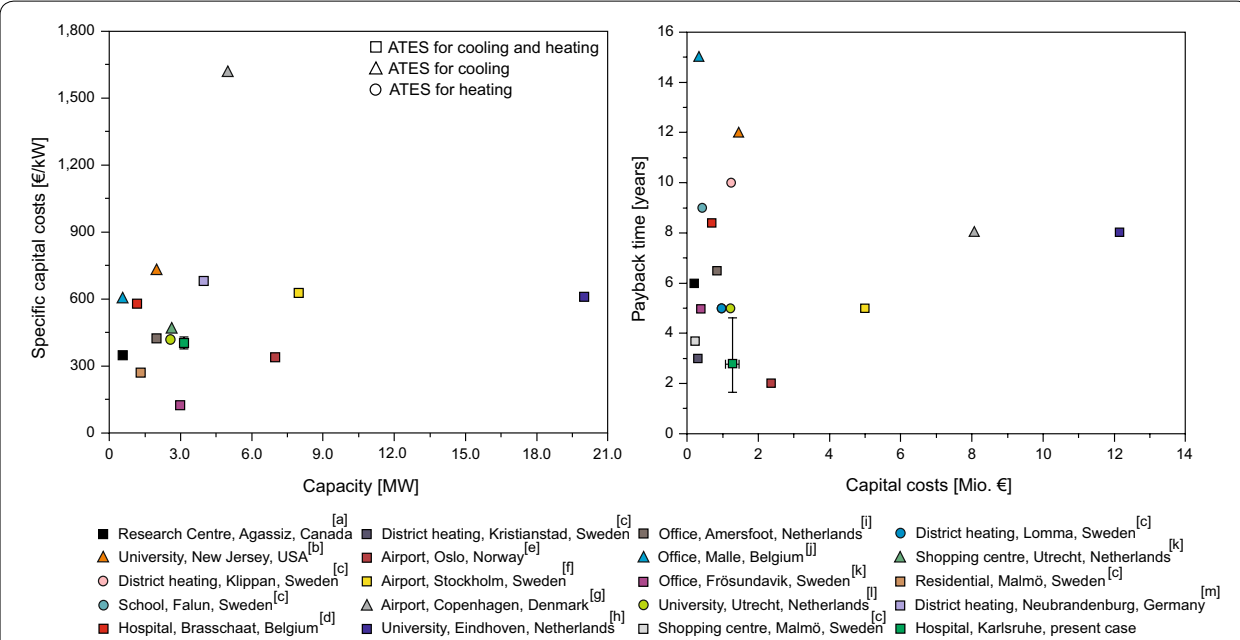

Fig. 9 Specific capital costs, capacity and payback times of different ATES systems in operation. ${ }^{a}$ Bridger and Allen (2010), baksoy et al. (2009), ' Andersson and Sellberg (1992), 'Vanhoudt et al. (2011), 'Eggen and

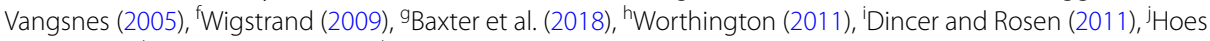
et al. (2006), kBakema et al. (1994), 'Sanner (2000)

payback times higher than 8 years are among the very first systems implemented during the 1980s and early 1990s (Utrecht, Klippan, Falun) or are related to research (Agassiz, New Jersey). Lack of experience and focus on scientific issues could lead to a less efficient operation, resulting in higher payback times. Figure 8 demonstrates that the hybrid ATES of the present study have shorter payback times than the ATES only for heating and cooling. Figure 9 clearly confirms this result and shows that hybrid ATES systems potentially have much lower payback times with an average of 5.6 years compared to the two Swedish ATES for heating or the ATES systems used exclusively for cooling. In addition, the maximum payback time of all of the hybrid ATES systems in Fig. 9 is 8.4 years (Brasschaat, Belgium), which strongly corresponds with the estimated maximum payback time of 8.7 years of the present study. The ATES for heating and cooling of the Klina hospital in Brasschaat, Belgium, has a capacity of $1.2 \mathrm{MW}$ and is a rare example of an ATES which is comprehensively described in the literature (Desmedt and Hoes 2007; Hoes et al. 2006; Vanhoudt et al. 2011). Thus, this ATES is compared in more detail with the ATES of the present study (Table 10).

The specific capital costs of the ATES in Belgium are $580 € / \mathrm{kW}$ and $28 \%$ higher than the estimated specific capital costs in the present study. This is almost equivalent to the reverse ratio of the number of wells with two in Braasschat and six in the present study. This again confirms the large sensitivity of the well construction to the capital costs. In total, the ATES of the Klina hospital saves $85 \%$ of energy compared to gas boilers and cooling machines. This is $9 \%$ more than the ATES in the present study, mostly resulting from the lower estimated SPF of the reference cooling machines in Belgium. Assuming that the compression chillers of the present study have the same COP, the percentage share of saved energy (88\%) by the ATES is almost equal to the Belgium ATES. This shows that the economic comparison in the present study between the ATES for cooling and the compression chillers is a rather conservative approach. Thus, ATES for 


\begin{tabular}{|c|c|c|c|}
\hline & Parameter & ATES present study & ATES Klina hospital \\
\hline \multirow[t]{6}{*}{ General } & Capital costs $(k €)$ & $1258( \pm 80)$ & 695 \\
\hline & Capacity (MW) & 3.0 & 1.2 \\
\hline & Number of wells & 6 & 2 \\
\hline & Well depths & 35 & 65 \\
\hline & $\Delta T(\mathrm{~K})$ & 4 & $\sim 10$ \\
\hline & Electricity costs (ct/kWh) & $16.5( \pm 0.5)$ & 11.0 \\
\hline \multirow[t]{4}{*}{ Heating } & Energy demand (MWh) & 3685 & 1335 \\
\hline & Efficiency & $3.6-4.4$ (COP) & 5.9 (SPF) \\
\hline & $\begin{array}{l}\text { Reference technology [heating } \\
\text { costs (ct/kWh)] }\end{array}$ & District heating $(8.83( \pm 1.26))$ & Gas boiler (3.50) \\
\hline & Energy savings (\%) & 75.0 & 85.6 \\
\hline \multirow[t]{4}{*}{ Cooling } & Energy demand (MWh) & 4800 & 1335 \\
\hline & Efficiency & 29 (COP) & 26 (SPF) \\
\hline & Reference technology (COP) & Compression chillers (COP 5.0-7.0) & Cooling machines (SPF 3.5) \\
\hline & Energy savings (\%) & 80 & 87 \\
\hline
\end{tabular}

cooling can potentially save even more energy compared to compression chillers resulting in an even better economic viability. However, the present study shows that even though the efficiency of compression chillers will improve in the future, ATES for cooling is still more economical. Despite larger relative savings of energy, the payback time of the ATES in Belgium is higher than the average payback time in the present study. This mainly results from the low heating costs of the reference gas boiler system, despite an efficiency of only $85 \%$ and the relatively high capital costs for this specific ATES system as shown in Fig. 9. Transferred to the heating demand of the hospital in the present study, the demand-related costs of gas boilers under Belgian conditions are 130,000 $€$ (46\%) lower compared to the district heating in Karlsruhe. Considering the current gas price in Karlsruhe of $5.2 \mathrm{ct} / \mathrm{kWh}$ (Stadtwerke Karlsruhe 2016), gas-driven heat pumps for ATES systems can also be considered from an economic perspective, however, not from a perspective of sustainability.

\section{ATES system in practice}

The design of an ATES system can deviate strongly from the approach of the present study depending on the local conditions. In contrast to the present study, the large imbalance between the extracted and reinjected heating and cooling energy can be a major issue in practice. The much larger cooling demand of the building (Table 1) can result in a successive temperature increase of the aquifer after some periods. This could lead to conflicts with water authorities or neighbouring installations as well as to a significant loss of efficiency, mainly in terms of direct cooling. If the aquifer temperature becomes insufficient for direct cooling, additional cooling machines must be activated which greatly increases the electricity consumption and demand-related costs of the system. To compensate for the larger amount of heat energy in the injection well as a result of the higher cooling demand, additional installations such as cooling towers, recooling plants, heat pumps or air handling units are used (Ghaebi et al. 2017; Kranz and 
Frick 2013; Paksoy et al. 2009; Vanhoudt et al. 2011). Another approach to achieve thermal balancing is night ventilation of a building. This reduces the cooling demand on the ATES which results in a decreased quantity of heat injection (Bozkaya and Zeiler 2019). However, most of these measures are related to additional expenses, which are not considered in the present study. In contrast to the present study, ambient temperatures and heating and cooling demands can vary within a short period of time. To comprehensively understand the impact of energy demand variations or hydrogeological changes in the subsurface on the economic performances of ATES, more simulations tools should be used in the future. Since ATES is a rather slow acting system, additional supply technologies also for peak loads are needed. Thus, buildings often partially use ATES in combination with compression and/or absorption chillers for cooling and boilers and/or CHP systems for heating (Holstenkamp et al. 2017; Kabus and Seibt 2000). Experience from other countries shows that adjustments from the authorities allow the number of LT-ATES installations to grow (Fleuchaus et al. 2018). In the Netherlands, a hospital similar to that in the present case is less restricted by authorities and would perhaps have decided otherwise. Future ATES projects can only be successfully implemented in Germany if the responsible house builder, technical building planners, building technicians, as well as public and local water authorities closely cooperate in the early stages of the planning process. Furthermore, an extensive and permanent system to monitor the subsurface installation and the building connection is an important factor of ATES systems ensuring the long-term and sustainable operation of the systems as it is assumed in the present study.

\section{Environmental analysis}

Figure 10 illustrates the $\mathrm{CO}_{2}$ emissions of the different supply technologies. The replacement of the reference technology with the ATES systems for heating and cooling results in an expected average $\mathrm{CO}_{2}$ emission savings of $262 \mathrm{t} /$ year (36\%). Considering the observation time of 30 years, $7854 \mathrm{t} \mathrm{CO}_{2}$ could potentially be saved. The defined $\mathrm{CO}_{2}$ savings of the present study are within the range of $\mathrm{CO}_{2}$ savings of ATES systems in the Netherlands, varying between 150 and 1500 t/year (Fleuchaus et al. 2018). However, much higher amounts of $\mathrm{CO}_{2}$ savings are feasible. The ATES system for the heating and cooling of the University of Technology in Eindhoven with a capacity of $20 \mathrm{MW}$ achieves $\mathrm{CO}_{2}$ emissions savings of 13,000 t/year (Snijders and van Aarssen 2003; Worthington 2011).

The relative $\mathrm{CO}_{2}$ savings for direct cooling compared to the compression chillers are equivalent to the energy savings. Both systems are driven by electricity and therefore have the same emission factor. Per $\mathrm{m}^{3}$ of pumped groundwater for direct cooling, approximately $0.27 \mathrm{~kg}$ of $\mathrm{CO}_{2}$ are saved. District heating has a low emission factor at the studied site and can therefore compete with renewable energies. Thus, the relative amount of saved energy does not always correlate with the percentage of $\mathrm{CO}_{2}$ savings. However, it is important to consider that the environmental evaluation excludes the $\mathrm{CO}_{2}$ emissions resulting from the heat sources of the district heating. A life cycle assessment (LCA) would provide a more detailed and comprehensive analysis about the potential environmental benefits of the ATES system. Depending on the replaced system and the emission factor, most of the ATES systems discussed in literature save around $60 \%$ of 


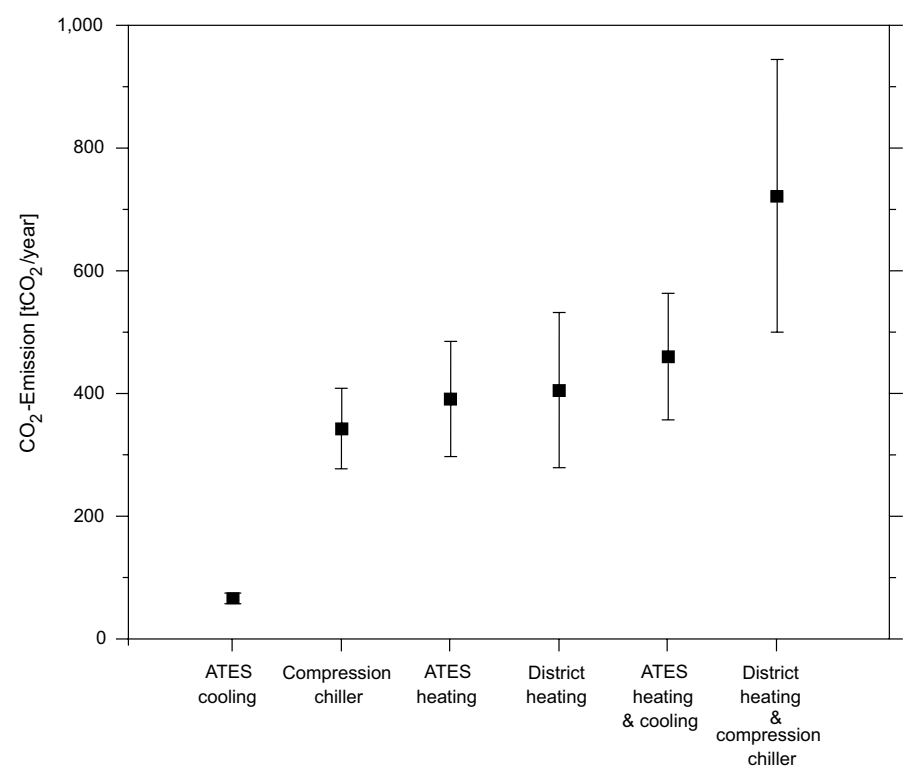

Fig. 10 Annual $\mathrm{CO}_{2}$ emissions of the compared technologies for the heating and cooling supply of the hospital building

$\mathrm{CO}_{2}$ emissions during operation (Kabus and Seibt 2000; Paksoy et al. 2009). Based on the studied literature, ATES systems, which save less than $60 \%$ of $\mathrm{CO}_{2}$ emissions, are compared with reference technologies associated with a lower emission factor than the emission factor of electricity.

Considering the environmental damage caused by $\mathrm{CO}_{2}$ emissions, even more costs can be saved by the implementation of ATES. According to the Federal Environmental Agency, $1000 \mathrm{~kg}$ of emitted $\mathrm{CO}_{2}$ cause environmental damages of $180 €$ (Umweltbundesamt 2018). In the context of our results, the replacement of the reference technology with the ATES potentially reduces the environmental damages by 1.4 million $€$ after 30 years of operation. Converted to the supplied energy in the present study, the ATES causes expected environmental damages of $0.007 \mathrm{ct} / \mathrm{kWh}$, which is half the amount produced by wind energy $(0.014 \mathrm{ct} / \mathrm{kWh})$ and only a small fraction of the environmental damages of lignite-based electricity of $20.81 \mathrm{ct} / \mathrm{kWh}$ (Umweltbundesamt 2018).

\section{Conclusion}

Decision makers and stakeholders should be aware of the composition of the capital costs with the main expenses of $60 \%$ related to the underground section of the ATES system. The expected payback time of the present study (2.7 years) and of other ATES systems (less than 10 years) should raise the awareness of the potential economic benefits of ATES despite higher capital costs. The most efficient usage of ATES is for both the heating and cooling supply of a building. Thus, we recommend ATES operating as hybrid systems for heating and cooling particularly in countries where ATES is not yet common. However, since the economic competitiveness of ATES in regard to sustainable technologies has not yet been examined in detail, further comprehensive analyses are needed. In the long-term, the number of installed ATES will only increase, if there is an economic benefit, a higher reliability and a wide social acceptance compared to 
competing renewable technologies. In addition, further studies should be performed to fully understand the benefit of ATES towards open geothermal systems such as groundwater heat pump (GWHP) systems without active storage, which are already frequently used in Germany. For this reason, important parameters such as the $\Delta T$ as well as the different flow temperatures of the heat pumps between ATES and GWHP systems need to be studied in more detail. Additionally, monitoring and evaluation of ATES systems already in operation need to be improved and intensified with focus on injection and extraction temperatures, performance of the submersible pumps, volume flows, efficiency of the heat pumps as well as the efforts for maintenance. Thus, site-specific parameters instead of generic values could lead to a greater accuracy and better transparency of techno-economic analyses of ATES systems. Finally, as many large buildings are likely to require more cooling than heating, for example hospitals and data centres, the effects of larger cooling demands of buildings on the economics of ATES and associated preventing measures should be investigated.

\section{List of symbols}

\section{Latin symbols}

ATES: Aquifer Thermal Energy Storage; BP: basic price $(€)$; $c_{\mathrm{a}}$ : volumetric heat capacity aquifer $\left(\mathrm{MJ} / \mathrm{m}^{3} \mathrm{~K}\right)$; C: capital costs $(€)$; CAD: Canadian Dollar; CC: current costs $(€)$; $\mathrm{CCH}$ : compression chiller; $\mathrm{CCO}$ : cooling costs $(€)$; $\mathrm{CE}: \mathrm{CO}_{2}$ emission per year $\left(\mathrm{tCO}_{2} /\right.$ year); $\mathrm{CH}$ : heating costs $(€)$; $\mathrm{CHP}$ : combined heat and power; COP: coefficient of performance; $\mathrm{CP}$ : commodity price $(\mathrm{ct} / \mathrm{kWh}) ; \mathrm{C}_{\mathrm{w}}$ : volumetric heat capacity water $(\mathrm{MJ} /$ $\left.\mathrm{m}^{3} \mathrm{~K}\right)$; DC: demand-related costs $(€)$; $\mathrm{DH}$ : district heating; g: gravity $\left(\mathrm{m} / \mathrm{s}^{2}\right)$; E: electricity consumption (kWh, MWh); el: electricity; EC: electricity costs (ct/kWh); ED $\mathrm{H}_{\mathrm{H}}$ : heating demand (kWh, MWh); $\mathrm{ED}_{\mathrm{C}}$ : cooling demand (kWh, MWh); EF: emission factor ( $\mathrm{t} /$ MWh); g: gravity $\left(\mathrm{m} / \mathrm{s}^{2}\right)$; EUR: Euro; GSHP: ground source heat pump; h: delivery head (m); H: well depth (m); HP: heat pump; HT-ATES: high temperature ATES; i: discount rate; k: 1000; L: Screen length (m); LT-ATES: low-temperature ATES; M: maintenance; MiRO: mineral oil refinery; NLG: Gulden; NPV: net present value $(€)$; OC: operationrelated costs $(€)$; P: power submersible pump $(\mathrm{kW})$; PP: power price $(€ / \mathrm{kW})$; q: pumping rate $\left(\mathrm{m}^{3} / \mathrm{h}\right)$; $\mathrm{q}^{\mathrm{T}}$ : interest factor; Q: energy from ATES $(\mathrm{kWh}, \mathrm{MWh})$; $\mathrm{R}$ : replacement; $\mathrm{R}_{\mathrm{th}}$ : thermal radius $(m) ; R_{t}$ : return at time $t$; SPF: seasonal performance factor; $t:$ time $(s, h$, d); $\Delta \mathrm{T}$ : temperature difference $(\mathrm{K}) ; \mathrm{t}_{\mathrm{H}}$ : heating period $(\mathrm{h})$; $\mathrm{t}_{\mathrm{C}}$ : cooling period $(\mathrm{h})$; $\mathrm{T}$ : payment date (a); USD: US-Dollar; V: volume of pumped groundwater $\left(\mathrm{m}^{3}\right)$; VDI: Verein Deutscher Ingenieure.

\section{Greek symbols}

$\rho$ : density $\left(\mathrm{kg} / \mathrm{m}^{3}\right) ; \eta$ : efficiency.

\section{Authors' contributions}

SS, PF and PB developed the methodology and designed the study. SS carried out the data collection, the data analysis and prepared the draft of the manuscript. All authors read and approved the final manuscript.

Author details

${ }^{1}$ European Institute for Energy Research (EIFER), Emmy-Noether-Straße 11, 76131 Karlsruhe, Germany. ${ }^{2}$ Institute of Applied Geosciences (AGW), Karlsruhe Institute of Technology (KIT), Kaiserstraße 12, 76131 Karlsruhe, Germany.

\section{Acknowledgements}

The authors would like to thank Roland Stindl environmental representative of the municipal hospital of Karlsruhe for providing us with helpful information about the hospital. The helpful comments of the two reviewers are also gratefully acknowledged. 
Competing interests

The authors declare that they have no competing interests.

Availability of data and materials

The relevant datasets analysed in this study are all presented in the manuscript.

\section{Funding}

This study is funded through the funding programme BWPLUS by the Ministry of the Environment, Climate Protection and the Energy Sector Baden-Württemberg (Grant Number L7516014-16019).

\section{Publisher's Note}

Springer Nature remains neutral with regard to jurisdictional claims in published maps and institutional affiliations.

Received: 5 February 2019 Accepted: 15 April 2019

Published online: 24 April 2019

\section{References}

Andersson O, Sellberg B (1992) Swedish ATES applications: experiences after ten years of development. In: Jenne EA (ed) Aquifer thermal energy (heat and chill) storage: proceedings of the 27th 521 intersociety energy conversion engineering conference, San Diego, p. 1-9.

Andersson O, Ekkestubbe J, Ekdahl A. UTES (underground thermal energy storage)—applications and market development in Sweden. J Energy Power Eng. 2013;7:669-78.

Bakema G, Snijders AL, Nordell B (1994) International energy agency: implementing agreement for a programme of research and development on energy conservation through energy storage. Evaluation underground thermal energy storage state of the art.

Baxter G, Srisaeng P, Wild G. An assessment of airport sustainability, Part 2-energy management at Copenhagen Airport. Resources. 2018;7:32. https://doi.org/10.3390/resources7020032.

Bayer P, Saner D, Bolay S, Rybach L, Blum P. Greenhouse gas emission savings of ground source heat pump systems in Europe: a review. Renew Sustain Energy Rev. 2012;16:1256-67. https://doi.org/10.1016/j.rser.2011.09.027.

Behi M, Mirmohammadi SA, Suma AB, Palm BE (2014) Optimized energy recovery in line with balancing of an ATES. In: Proceedings of the ASME 2014 Power Conference, Balitmore, Maryland.

Bloemendal M, Hartog N. Analysis of the impact of storage conditions on the thermal recovery efficiency of low-temperature ATES systems. Geothermics. 2018;71:306-19. https://doi.org/10.1016/j.geothermics.2017.10.009.

Bloemendal M, Olsthoorn T. ATES systems in aquifers with high ambient groundwater flow velocity. Geothermics. 2018;75:81-92. https://doi.org/10.1016/j.geothermics.2018.04.005.

Bloemendal M, Olsthoorn T, Boons F. How to achieve optimal and sustainable use of the subsurface for Aquifer Thermal Energy Storage. Energy Policy. 2014;66:104-14. https://doi.org/10.1016/j.enpol.2013.11.034

Bloemendal M, Jaxa-Rozen M, Olsthoorn T. Methods for planning of ATES systems. Appl Energy. 2018;216:534-57. https:// doi.org/10.1016/j.apenergy.2018.02.068.

Blohm H, Lüder K, Schaefer C. Investition: Schwachstellenanalyse des Investitionsbereichs und Investitionsrechnung. 9th ed. München: Vahlen; 1995.

Bloomquist RG (2000) Geothermal heat pumps five plus decades of experience in the United States. In: Proceedings World Geothermal Congress, Kyushu-Tohoku, Japan.

Boissavy C (2015) Cost and return on investment for geothermal heat pump systems in France. In: Proceedings world geothermal congress, Melbourne, Australia, 19-25 April.

Bonte M, van Breukelen BM, Stuyfzand PJ. Environmental impacts of Aquifer Thermal Energy Storage investigated by field and laboratory experiments. J Water Clim Change. 2013;4:77-89. https://doi.org/10.2166/wcc.2013.061.

Bozkaya B, Zeiler W. The effectiveness of night ventilation for the thermal balance of an aquifer thermal energy storage. Appl Therm Eng. 2019;146:190-202. https://doi.org/10.1016/j.applthermaleng.2018.09.106.

Bridger DW, Allen DM. Designing Aquifer Thermal Energy Storage systems. ASHRAE. 2005;47:32-7.

Bridger DW, Allen DM. Heat transport simulations in a heterogeneous aquifer used for Aquifer Thermal Energy Storage (ATES). Can Geotech J. 2010;47:96-115. https://doi.org/10.1139/T09-078.

Bundesministerium für Wirtschaft und ENergie (2017) Zahlen und Fakten Energiedaten: Nationale und internationale Entwicklung. Entwicklung von Energiepreisen und Preisindizes zu nominalen Preisen Deutschland.

Chant V, Morofsky E (1992) Overview of projects with seasonal storage for cooling. In: Jenne EA (ed) Aquifer thermal energy (heat and chill) storage: proceedings of the 27th 521 intersociety energy conversion engineering conference, San Diego, p. 17-21.

Chiasson A, Culver G (2006) Final report feasibility study for HVAC retrofit with a geothermal system Mount Grant General Hospital, Hawthorne, NV.

Desmedt J, Hoes H (2007) Monitoring results of Aquifer Thermal Energy Storage system in a Belgian hospital. In: 2nd PALENC COnference and 28th AIVC COnference on Building Low Energy Cooling and Advanced Ventilation Technologies in the 21st Century.

Dickinson J, Buik N, Matthews M, Snijders A. Aquifer thermal energy storage: theoretical and operational analysis. Géotechnique. 2008;58:1-12. https://doi.org/10.1680/geot.2008.58.00.1.

Dincer I, Rosen M. Thermal energy storage: systems and applications. 2nd ed. London: Wiley; 2011.

Eggen G, Vangsnes G. Heat pump for district cooling and heating at Oslo Airport Gardermoen. NV: Las Vegas; 2005. 
EnbW (2017) $\mathrm{CO}_{2}$-Fußabdruck und Energieeffizienz: Spezifische $\mathrm{CO}_{2}$-Emissionen: Spezifische $\mathrm{CO}_{2}$-Emissionen der Eigenerzeugung Strom. https://www.enbw.com/unternehmen/konzern/ueber-uns/umweltschutz/co2/. Accessed 29 Jan 2019.

Engie (2016) ENGIE Refrigeration kühlt den WDR rund um die Uhr.

Engie (2018) Der Weg zum gesunden Klima: Energieeffiziente Kältemaschinen und Serbives für Kliniken und Krankenhäuser.

Fair Energy (2018) TÜV Zertifikat CO 2 Emissionsfaktor. https://www.fairenergie.de/inhalt/privatkunden/fernwaerme.html. Accessed 29 Jan 2019.

Fleuchaus P, Godschalk B, Stober I, Blum P. Worldwide application of aquifer thermal energy storage-a review. Renew Sustain Energy Rev. 2018;94:861-76. https://doi.org/10.1016/j.rser.2018.06.057.

Ghaebi H, Bahadori MN, Saidi MH. Economic and environmental evaluations of different operation alternatives of an Aquifer Thermal Energy Storage in Tehran, Iran. Scientia Iranica. 2017;24:610-23. https://doi.org/10.24200/ sci.2017.4046.

GHJ (2017) Ingenieurgesellschaft für Geo- und Umwelttechnik: Kostenschätzung Geothermieanlage.

Gudmundsson O, Thorsen JE, Zhang L. Cost analysis of district heating compared to its competing technologies. WIT Trans Ecol Environ. 2013;176:3-13. https://doi.org/10.2495/ESUS130091.

GWE (2017) German Water and Energy Group. Preisliste.

Hähnlein S, Bayer P, Blum P. International legal status of the use of shallow geothermal energy. Renew Sustain Energy Rev 2010;14:2611-25. https://doi.org/10.1016/j.rser.2010.07.069.

Hähnlein S, Bayer P, Ferguson G, Blum P. Sustainability and policy for the thermal use of shallow geothermal energy. Energy Policy. 2013;59:914-25. https://doi.org/10.1016/j.enpol.2013.04.040.

HallamICS (2012) Montpelier district heating cost estimate.

Hartog N, Drijver B, Dinkla I, Bonte M (2013) Field assessment of the impacts of Aquifer Thermal Energy Storage (ATES) systems on chemical and microbial groundwater composition. In: Proceedings of the European Geothermal Conference, Pisa, Italy.

Heinrich C, Wittig S, Albring P, Richter L, Safarik M, Böhm U, Hantsch A (2014) Nachhaltige Kälteversorgung in Deutschland an den Beispielen Gebäudeklimatisierung und Industrie: Im Auftrag des Umweltbundesamtes.

Hendriks M, Velvis H (2012) Operational management of large scale UTES systems in hospitals. In: Innostock 2012 the 12th international conference on energy storage.

Hoes H, Desmedt J, Robeyn N, van Bael J (2006) Experience with ATES applications in Belgium: operational results and energy savings In: Ecostock—conference proceedings. Stockton University, NJ, USA.

Holstenkamp L, Meisel M, Neidig P, Opel O, Steffahn J, Strodel N, Lauer JJ, Vogel M, Degenhart H, Michalzik D, Schomerus T, Schönebeck J, Növig T. Interdisciplinary review of medium-deep Aquifer Thermal Energy Storage in North Germany. Energy Procedia. 2017;135:327-36. https://doi.org/10.1016/j.egypro.2017.09.524.

Institut für Energie- und Umwelttechnik (2002) Preisatlas-Ableitung von Kostenfunktionen für Komponenten der rationellen Energienutzung.

International Energy Agency (2007) Renewables for heating and cooling: untapped potential. Renewable energy technology deployment.

Kabus F, Seibt P (2000) Aquifer Thermal Energy Storage for the Berlin Reichtstag building—new seat of the German parliament. In: Proceedings World Geothermal Congress. Kyushu—Tohoku, Japan.

Kabus F, Wolfgramm M, Seibt A, Richlak U, Beuster H (2009) Aquifer Thermal Energy Storage in Neubrandenburg—-monitoring throughout three years of regular operation.

Kalaiselvam S, Parameshwaran R. Thermal energy storage technologies for sustainability: systems design, assessment, and applications. 1st ed. Amsterdam: Elsevier AP: 2014.

Kangas TA, Lund PD. Modelling and simulation of aquifer storage energy systems. Sol Energy. 1994;53:237-47.

Konstantin P (2017) Praxisbuch Energiewirtschaft: Energieumwandlung, -transport und -beschaffung, Übertragungsnetzausbau und Kernenergieaussstieg, 4th edn. Springer Vieweg.

Kranz S, Frick S. Efficient cooling energy supply with aquifer thermal energy storages. Appl Energy. 2013;109:321-7.

LANUV (2004/2005) Landesumweltamt Nordrhein-Westfalen. Leistungsbuch Altlasten \& Flächenentwicklung: Leistungsbereich 24 Brunnenbau.

LANUV (2015) Landesamtes für Natur, Umwelt und Verbraucherschutz Nordrhein-Westfalen. Leistungsbuchs Altlasten und Flächenentwicklung. http://www.leistungsbuch.de/Frontend/lbuKatalog/KatalogForm.aspx. Accessed 29 Jan 2019.

Larsen HH, Petersen LS (2015) DTU international energy report 2015. Energy systems integration for the transition to non-fossil energy systems, Technical University of Denmark.

Liang X, Fleming E (2012) Power consumption evaluation for electrical submersible pump systems: 20-24 May 2012, Louisville, KY. In: IEEE/IAS 48th Industrial \& Commercial Power Systems Technical Conference (I\&CPS).

MacKenzie W, Cusworth N (2007) The use and abuse of feasibility studies. In: Project evaluation conference Melbourne.

Natural Resources Canada (2019) RETScreen. https://www.nrcan.gc.ca/energy/software-tools/7465. Accessed 29 Jan 2019.

Nordell B, Snijders A, Stiles L. The use of aquifers as thermal energy storage (TES) systems. In: Cabeza LF, editor. Advances in thermal energy storage systems: methods and applications. Cambridge: Woodhead Publishing Limited; 2015. p. $87-115$.

Paksoy H, Snijder A, Stiles L (2009) State-of-the-art review of aquifer thermal energy storage systems for heating and cooling buildings. In: Proceedings Effstock. 11th international conference on thermal energy storage for energy efficiency and sustainability, Stockholm, Sweden.

Palisade (2019) @Risk ein neuer Standard für die Risikoanalyse. https://www.palisade.com/risk/de/. Accessed 29 Jan 2019.

Queensland Government. Project cost estimating manual. 6th ed. Brisbane: Queensland Government; 2015.

Reilly RW, Brown, Huber HD (1981) Aquifer thermal energy storage costs with a seasonal heat source. https://doi. org/10.2172/5233922. 
Rosen M, Koohi-Fayegh S. Geothermal energy: Sustainable heating and cooling using the ground. Chichester: Wiley; 2017.

Sanner B (2000) ECES annex 12 high temperature underground thermal energy storage.

Schäfer V, Negele B (2009) Absorptionskältemaschinen—Anwendungsbeispiele. KI Kälte Luft Klimatechnik:26-31.

Schlott S (2001) Kälteerzeugung für die Klimatechnik mit einer Kompressions- oder Absorptionsmaschine mit Fernwärme.

Seider WD. Equipment sizing and capital cost estimation. Product and process design. Philadelphia: University of Pennsylvania; 2006

Snijders AL (2005) Aquifer thermal energy storage in the Netherlands: status beginning of 2005.

Snijders AL, van Aarssen MM (2003) Big is beautiful?: application of large-scale energy storage in the Netherlands. In: Futurestock' 9 th international conference on the thermal energy storage, Warsaw, Poland.

Sommer W, Valstar J, van Gaans P, Grotenhuis T, Rijnaarts H. The impact of aquifer heterogeneity on the performance of aquifer thermal energy storage. Water Resour Res. 2013;49:8128-38. https://doi.org/10.1002/2013WR013677.

Sommer W, Valstar J, Leusbrock I, Grotenhuis T, Rijnaarts H. Optimization and spatial pattern of large-scale aquifer thermal energy storage. Appl Energy. 2015;137:322-37. https://doi.org/10.1016/j.apenergy.2014.10.019.

Stadtwerke Emmendingen (2019a) Fernwärme. https://swe-emmendingen.de/fernwarme/. Accessed 29 Jan 2019.

Stadtwerke Emmendingen (2019b) Preisblatt Wärmelieferung_-Preisstand 01.01.2019.

Stadtwerke Karlsruhe (2016) Allgemeine Preise im Rahmen der Grundversorgung.

Stadtwerke Karlsruhe (2017) Umwelterklärung 2017 mit Klimareport und Energiebericht: Aktualisierte Kennzahlen.

Stadtwerke Karlsruhe (2018) Fernwärme.

Stadtwerke Pforzheim (2019) Fernwärmeversorgung der SWP. https://www.stadtwerke-pforzheim.de/fernwaerme/preis e. Accessed 29 Jan 2019

Stadtwerke Sindelfingen (2007) Planbare Kosten—die Hausanschlusspauschalen.

Stadtwerke Sindelfingen (2018) Hausanschlusskosten Fernwärme.

Stadtwerke Ulm (2018) SWU Energie GmbH Preisblatt für Fernwärme.

Stadtwerke Waldkraiburg (2018) Preisblatt geothermale Fernwärmeversorgung der Stadtwerke Waldkraiburg GmbH.

Umweltbundesamt (2018) Hohe Kosten durch unterlassenen Umweltschutz.

van Beek D, Godschalk B (2013) Regeocities. Regulative framework in the Netherlands.

van Hove J. Productivity of Aquifer Thermal Energy Storage (ATES) in The Netherlands. Tunn Undergr Space Technol. 1993;8:47-52. https://doi.org/10.1016/0886-7798(93)90136-J.

Vanhoudt D, Desmedt J, van Bael J, Robeyn N, Hoes H. An aquifer thermal storage system in a Belgian hospital: long-term experimental evaluation of energy and cost savings. Energy Build. 2011;43:3657-65. https://doi.org/10.1016/j.enbui ld.2011.09.040.

VDI 2067 (2012) Economic efficiency of building installations: Fundamentals and economic calculations.

viamedica (2009) Erneuerbare Energien und Energieeffizienz in deutschen Kliniken.

Wigstrand I (2009) The ATES project-a sustainable solution for Stockholm-Arlanda airport. In: 11th international conference on thermal energy storage for energy efficiency and sustainability, Stockholm, Sweden.

Worthington MA (2011) Aquifer thermal energy storage: an enabling green technology for campus district energy systems: IDEA. In: Proceedings of 24th annual campus energy conference, Miami, US

Zimmerman PW, Drost MK (1989) Cost analysis of power plant cooling using aquifer thermal energy storage. Prepared for the U.S. Department of Energy under Contract DE-AC06-76RLO 1830. Pacific Northwest Laboratory. https://doi. org/10.2172/5962306

\section{Submit your manuscript to a SpringerOpen ${ }^{\circ}$ journal and benefit from:}

- Convenient online submission

- Rigorous peer review

- Open access: articles freely available online

- High visibility within the field

- Retaining the copyright to your article

Submit your next manuscript at $\boldsymbol{\Delta}$ springeropen.com 